References

1. Arunin L.I., Kapuller L.L., Isakov V.A. Morphological diagnosis of diseases of the stomach and intestines. Triada-X, 1998:496p

2. Bacon C., Ming-Qing Du, Dogan A. Mucosa-associated lymphoid tissue (MALT) lymphoma: a practical guide for pathologists. J. Clin. Pathol. 2007;60:361-372.

3. Ivashkin V.T. Meditsinskii Vestnik Severnogo Kavkaza. Medical News of North Caucasus. 2006;19(362):9-10.

4. Kamishnikov V.S. Handbook of clinical and biochemical research laboratory diagnostics. Moscow: MEDpressinform. 2004.

5. Korzhevsky D.E. Basics of histologic techniques. Moscow: Meditsina, 2010:234p.

6. Okabe S., Amagase K. An overview of acetic acid ulcer models. The history and state of the art of peptic ulcer research. Biol. Pharm. Bull. 2005;8(28):1321-1341.
7. Okorokov A.N. Diagnosis of diseases of the internal organs: Volume 1. Diagnosis of diseases of the digestive system. Moscow: Med.lit. 2002:560p.

8. Parks W.C., Wilson C.L., López-Boado Y.S. Matrix metalloproteinases as modulators of inflammation and innate immunity. Nature Reviews Immunology. 2004;8(4):617-629.

9. Povetkina V.N., Rogova L.N. Vestnik novich meditsinskich technologiy. - Bulletin of new medical technologies. 2011;2(18):83-86.

10. Rubin H. The logic of the Membrane, Magnesium, Mitosis (MMM) model for the regulation of animal cell proliferation. Science. 2003;261:1280-1281.

11. Staravoitov V.A., Rogova L.N., Stacenko M.E. Vestnik Rossiiskogo universiteta druzhbi narodov (Medicina) Bulletin of the Russian Peoples' Friendship University (medicine series). 2008;7:532-534.

12. Troshin I.Yu., Gromova O.A. Kardiologiya - Cardiology. 2008; 10:14-21.

About authors:

Rogova Lyudmila Nikolaevna, Professor, Doctor of Medical Science; Head of Department for Pathophysiology, Clinical Pathophysiology, Kuban State Medical University, Russia; tel.: +7(8442)385364

Shesternina Natalya Vladimirovna, Candidate of Medical Science; Assistant Lecturer, Department for Pathophysiology Clinical Pathophysiology, Kuban State Medical University, Russia; tel. : +7(8442)385364

(c) Group of authors, 2015

UDC - 616.36-002:615.015

DOI - http://dx.doi.org/10.14300/mnnc.2015.10041

ISSN - 2073-8137

\title{
POSSIBILITIES OF ORIGINAL «BICYCLOL» MEDICINE IN THERAPY OF CHRONIC HEPATITIS C
}

Geyvandova N. I. ${ }^{1}$, Lioznov D. A. ${ }^{2}$, Morozov V. G. ${ }^{3}$, Yagoda A. V. ${ }^{1}$, Koroy P. V. ${ }^{1}$, Nikolaenko S. L. ${ }^{2}$, Glazkova E. Ja. ${ }^{3}$, Liu G. T. ${ }^{4}$, Han Ji. ${ }^{5}$

'Stavropol State Medical University, Stavropol, Russian Federation

${ }^{2}$ Pavlov First Saint Petersburg State Medical University, Saint Petersburg, Russian Federation

${ }^{3}$ Medical company uHepatologistı, Samara, Russian Federation

${ }^{4}$ Institute of Materia Medica, Chinese Academy of Medical Sciences, Beijing, China

${ }^{5}$ Xijing Hospital of Digestive Diseases, The Fourth Military Medical University, Xijing, China

\section{ВОЗМОЖНОСТИ ОРИГИНААЬНОГО ПРЕПАРАТА „БИЦИКАОА» В ТЕРАПИИ ХРОНИЧЕСКОГО ГЕПАТИТА С}

\author{
Н. И. Гейванаова ${ }^{1}$, А. А. Аиознов ${ }^{2}$, В. Г. Морозов ${ }^{3}$, А. В. ЯгоАа ${ }^{1}$, П. В. Корой ${ }^{1}$, \\ С. А. Николаенко ${ }^{2}$, Е. Я. ГАазкова ${ }^{3}$, Г. Т. $А и y^{4}$, И. Хан ${ }^{5}$
}

'Ставропольский госуАарственный меАицинский университет,
Ставрополь, Российская ФеАерация

${ }^{2}$ Первый Санкт-Петербургский госуАарственный меАицинский университет имени И.П. Павлова, Санкт-Петербург, Российская ФеАерация

${ }^{3}$ МК «Гепатологи, Самара, Российская Фелерация

${ }^{4}$ Институт "Материа МеАика" Китайской акаАемии МеАицинских наук,

Пекин, Китайская Народная Республика

${ }^{5}$ КсиАжинг госпиталь болезней органов пищеварения,

Четвертый Военный МеАицинский университет, КсиАжинг, Китайская Народная Республика

53 patients with chronic hepatitis $\mathrm{C}$ were treated in multicenter clinical trial: 26 female and 27 male, 23 have received antiviral therapy in a past. Inclusion criteria were follows: ALT activity $\geq 1.5$ ULN, absence of signs of liver cirrhosis decompensation and hepatocellular cancer. Bicyclol ${ }^{\circledR}$ medicine (Beijing Union Pharmaceutical Factory, PRC) was administered in a daily dose $150 \mathrm{mg}$ during 12 weeks. A primary efficacy criterion was ALT activity. There were decrease in ALT, AST activity and bilirubin level in patients who received Bicyclol ${ }^{\circledR}$, enhance in asthenic-vegetative syndrome as well. In the placebo group there were 
no such dynamics observed. Undesirable effects (UE) have been registered in 12 patients and appeared as a clinically negligible deviations in laboratory tests and were resulted from course of the main disease. In conclusions, Bicyclol ${ }^{\circledR}$ medicine has demonstrated efficacy in decrease of ALT activity, however no such effect was in placebo group. Tested medicine Bicyclol ${ }^{\circledR}$ is characterized with favorable safety profile and good tolerability. Bicyclol ${ }^{\circledR}$ use is reasonable in patients with active $\mathrm{CHC}$ with contraindications to antiviral treatment or after its fail.

Key words: chronic hepatitis $C$, pathogenetic therapy, bicyclol

В рамках мультицентрового клинического исследования пролечено 53 пациента хроническим гепатитом C (ХГC): 26 женщин и 27 мужчин, 23 больных ранее получали противовирусную терапию (ПВТ). Критерии включения: активность АлАТ в 1,5 и более раз выше нормы, отсутствие признаков декомпенсированного цирроза и гепато-целлюлярной карциномы. Препарат Бициклол (Веijing Union Pharmaceutical Factory, KHP) назначался в дозе 150 мг в сутки на 12 недель. Первичным критерием оценки эффективности выбрана активность АлАТ. У пациентов, принимавших Бициклол, наблюдалось снижение активности АлАТ, АсАТ и концентрации билирубина, а также уменьшение выраженности проявлений астено-вегетативного синдрома. В группе плацебо динамики этих показателей не наблюдалось. Нежелательные явления, отмеченные у 12 пациентов, проявлялись в виде клинически незначимых отклонений в лабораторных показателях и были связаны с течением основного заболевания. Препарат Бициклол продемонстрировал эффективность в виде снижения активности АлАТ при отсутствии такового в группе плацебо. Для препарата характерны благоприятный профиль безопасности и хорошая переносимость. Применение Бициклола целесообразно у пациентов с активным ХГС с наличием противопоказаний к ПВТ или после ее неудачи.

Ключевые слова: хронический вирусный гепатит $C$, патогенетическая терапия, бициклол

C hronic viral hepatitis $\mathbf{C}$ (CHC) is a major health and social problem because of its high prevalence, often progressive course and of the ability to result in severe final stages of the disease - cirrhosis and hepatocellular carcinoma. Currently, highly effective medicines with direct antiviral action, used in combination both with pegylated interferon (PegIFN) and in non-interferon combinations available on the pharmaceutical market $[1,2$, $6,10,13]$. However, due to the high price of most antiviral treatment (AVT) regimens of CHC availability of these drugs in a population of patients who require therapy is questionable, so standard regimens still remain valid. At the same time, there is a considerable number of patients with $\mathrm{CHC}$ who failed to respond to previous therapy with PegIFN and ribavirin or who have a contraindication to the treatment. Most of such patients have a high disease activity, which creates conditions for the rapid development of liver fibrosis. Therefore, an idea of hepatoprotective therapy that can reduce the activity of hepatitis and thus inhibit the rate of progression of fibrosis remains relevant.

Bicyclol is a unique innovative medicine created in an Institute of Materia Medica of Chinese Academy of Medical Sciences in a late 80-th of XX-th century. In order to develop novel antihepatitis drug, a number of analogues of the active component schizandrin C from Fructus Schiznadrae, a Chinese herb used in the therapy of viral hepatitis, were synthesized. Bicyclol, one of the analogues, was demonstrated to have actions of anti-hepatitis virus replication in duck hepatitis model and 2.2.15 cell line, anti-experimental liver injury induced by hepatotoxins such as $\mathrm{CCl} 4$, acetaminophen and ConA, and anti-liver fibrosis in rats and mice. The active mechanism of bicyclol might be anti-apoptosis of hepatocytes through multiple signaling pathways mainly inducing the expressions of hepatic heat shock proteins (HSP27 and HSP70), molecular chaperons. Nowadays Bicyclol is a widely used liver protectant in China and other countries, and its mechanism of action may be closely related to free radical-scavenging activities, protection against lipid peroxidation, protection of cell membranes and mitochondrial function [5], and inhibition of inflammatory cytokines [11].

Further studies have shown that bicyclol plays a role in eliminating free radicals, in preventing lipid peroxidation, and in protecting hepatic cell membrane and mitochondria in a number of models of hepatic injury [4]. Bicyclol can induce glutathione and glutathione-S-transferase expression, and inhibit the accumulation of hepatic lipids [7]. Some preliminary clinical trials showed that bicyclol was effective in improving hepatic functional indexes and histological scores in NAFLD patients [9], and in improving hepatic inflammatory necrosis in chronic hepatitis B patients without influencing the therapeutic effects of antiviral agents [12]. It was demonstrated in experimental and clinical studies that bicyclol could not only decrease serum transaminase levels, but could also lead to the improvements in pathological changes [7, 12]. Zhao et al. [14] revealed that the alleviating effects of bicyclol on hepatic inflammation was mainly due to its ability to attenuate oxidative stress, downregulate expression of tumor necrosis factor (TNF)$\alpha$ and interleukin- 6 , and then inhibit the secretion of cytokines such as TNF- $\alpha$.

Numerous basic in vitro \& in vivo studies demonstrated that bicyclol seems to be a multi- 
targeting drug as it can maintain biomembrane stability of hepatocyte via eliminating free radicals, protects against injury of mitochondria particularly inhibiting the release of cytochrome $\mathrm{C}$ to initiate apoptosis, inhibits hepatocyte nuclear DNA damage and related cellular signaling. All these effects of bicyclol should be the pharmacological bases of bicyclol in the treatment of chronic viral $B$ and $C$ hepatitis and non-viral hepatitis such as nonalcoholic fatty liver disease (NAFLD), alcoholic liver disease (ALD) and drug-induced (toxic) hepatitis [4].

The aim of the study was to evaluate the efficacy and safety of the Bicyclol tablets $25 \mathrm{mg}$ in adult patients with chronic hepatitis $\mathrm{C}$.

Material and Methods. "A randomized doubleblind placebo-controlled comparative study of efficacy and safety of the Bicyclol medicine in adult patients with chronic hepatitis C» included 59 patients, of which 23 have previously received AVT.

Inclusion criteria were: detectable HCV RNA levels in serum, ALT levels 1.5 times above the upper limit of laboratory standards or more (reference value of ALT: 0-50 U/L for men and 0-35 $U / L$ for women), duration of the disease for at least 6 months, no evidence of decompensated cirrhosis and hepatocellular carcinoma (HCC).

The study was carried out in three clinical centers in the Russian Federation: Samara Samara medical company «Hepatologist», Saint Petersburg - Pavlov First Saint Petersburg State Medical University, Stavropol - Stavropol State Medical University, from March 2013 to March 2014. The study was carried out in accordance with the Ministry of Health of the Russian Federation approval based on the ethical review results of the study protocol. Each center conducted coordination of the clinical study with local independent ethics committees. All patients included in the study gave an informed consent.

According to the protocol patients underwent routine laboratory tests: blood count, urine analysis, biochemical blood examination including the determination of ALT, AST, GGT, alkaline phosphatase, bilirubin and its fractions. The primary efficacy endpoint ALT activity was. Safety assessment was performed by recording and evaluation of adverse events (clinical examination, blood count and biochemical blood tests, urine analysis).

For the subjective measurement of asthenovegetative syndrome, a leading clinical manifestation of chronic viral hepatitis, the fatigue assessment scale was used MFI-20 (Multidimensional Fatigue Inventory-20) [8]. The scale MFI-20 includes 20 statements, the answer to each of which is scored from 0 to 5 points. Scoring is conducted with 5 subscales: general fatigue, physical fatigue, reduced activity, reduced motivation, mental fatigue. When the value of more than 12 points is recorded at least in one of the subscales and the total value amounts to more than 60 points a fatigue is considered significant.
Patients were randomized to the main (studied) or control groups received the tested medicine Bicyclol $^{\circledR}$ (Beijing Union Pharmaceutical Factory, China) or placebo, respectively. The dosage regimen for Bicyclol $^{\circledR}$ was in accordance with patient information leaflet: orally $50 \mathrm{mg}$ (2 tablets) 3 times a day (150 mg/day) one hour after meal. Placebo was administered in the same way. The duration of administration was 12 weeks. The values were evaluated before prescribing, after 4 and 12 weeks of therapy. Treatment compliance was determined by assessing the amount of medicine administered on 4th and 12th weeks of treatment. When the total missed doses comprised of more than $20 \%$ assigned dose (control by the number of tablets) compliance was considered unsatisfactory.

Statistical analysis of the results was performed using a software package for statistical analysis STATISTICA 10.0. When processing the results of the study bilateral statistical hypotheses with a significance level of 0.05 were considered. Data verification for the compliance with the normal distribution law was made using the Shapiro-Wilk test.

Comparison of the interval data results between groups of examined volunteers was carried using t-test (for normally distributed data) or with nonparametric Mann-Whitney test (for non-normal distribution). Comparison of the interval data results for the patients within the same group of volunteers was carried out using t-test for dependent samples (for normally distributed data) or with nonparametric Wilcoxon test (for data distribution other than normal). Comparison of categorical variables was performed using Fisher's exact test.

Results and Discussions. 59 patients were included in the study randomly by the screening results; 53 subjects formed ITT-population (included in the safety assessment). 51 patients have completed the treatment (PP-population included in the efficacy analysis). The study group (receiving Bicyclol) consisted of 34 patients aged 27 to 65 years (mean age -45.9 years $(S D=11.1)$ ), men - 53\% (18 subjects). The control group included 17 patients aged 25 to 64 years (mean age 47.5 years $(S D=11.6)$ ), men $-41 \%$ ( 7 subjects).

The diagnosis of chronic hepatitis $\mathrm{C}$ in patients of studied and control group was of $4.5(S D=4.8)$ and $4.9(S D=4.8)$ years, respectively. Before inclusion in the present study antiviral therapy of HCV (without sustained virological response (SVR)) was received by 12 patients (35.3\%) in the Bicyclol group and by 9 patients in the control group (52.9\%).

In terms of the frequency and severity of clinical manifestations of chronic viral hepatitis there were no differences between groups. Also, there were no differences in the quantitative level of HCV RNA (studied group - 4,09lg $(S D=0.95)$ and control group - 4.02lg ( $S D=0.81)$, respectively), and in main biochemical parameters in serum before the beginning of the therapy (Table 1 ). 
Main serum biochemical values in patients of the studied and control groups before the treatment

\begin{tabular}{|c|c|c|c|c|c|}
\hline Index & Group & $\mathrm{N}$ & Mean (M) & SD & p-value* \\
\hline \multirow{2}{*}{ ALT (U/I) } & Studied & 34 & 124.60 & 76.79 & \multirow{2}{*}{0.976} \\
\hline & Control & 17 & 120.92 & 74.57 & \\
\hline \multirow{2}{*}{ AST (U/I) } & Studied & 34 & 80.08 & 43.81 & \multirow{2}{*}{0.897} \\
\hline & Control & 17 & 80.47 & 41.93 & \\
\hline \multirow{2}{*}{$\begin{array}{c}\text { Total } \\
\text { bilirubin } \\
(\mu \mathrm{mol} / \mathrm{I})\end{array}$} & Studied & 34 & 17.50 & 8.03 & \multirow[b]{2}{*}{0.401} \\
\hline & Cor & 17 & 19.33 & 7.75 & \\
\hline \multirow{2}{*}{$\begin{array}{c}\text { Direct } \\
\text { bilirubin } \\
(\mu \mathrm{mol} / \mathrm{l})\end{array}$} & Studied & 34 & 4.75 & 2.48 & \multirow[b]{2}{*}{0.727} \\
\hline & Control & 17 & 4.94 & 2.40 & \\
\hline \multirow{2}{*}{$\begin{array}{l}\text { Indirect } \\
\text { bilirubin } \\
(\mu \mathrm{mol} / \mathrm{l})\end{array}$} & Studied & 34 & 12.75 & 6.60 & \multirow{2}{*}{0.281} \\
\hline & Control & 17 & 14.33 & 6.26 & \\
\hline \multirow{2}{*}{ GGT (U/I) } & Studied & 34 & 74.47 & 52.71 & \multirow[t]{2}{*}{0.583} \\
\hline & Control & 17 & 78.09 & 91.01 & \\
\hline \multirow{2}{*}{$\begin{array}{c}\text { Alkaline } \\
\text { phosphatase } \\
(\mathrm{U} / \mathrm{I})\end{array}$} & Studied & 34 & 111.11 & 50.94 & \multirow{2}{*}{0.442} \\
\hline & Control & 17 & 125.34 & 65.37 & \\
\hline \multirow{2}{*}{$\begin{array}{l}\text { TNF-a } \\
(\mathrm{pg} / \mathrm{ml})\end{array}$} & Studied & 34 & 2.38 & 1.21 & \multirow{2}{*}{0.477} \\
\hline & Control & 17 & 2.27 & 1.52 & \\
\hline
\end{tabular}

There were no differences between the groups in the evaluation of fatigue. On a scale of MFI-20 the results were borderline between normal and clinically significant, corresponding to the data of the physical examination of the patients and to physician assessment of the asthenovegetative syndrome severity.

It was shown a significant decrease in ALT activity in the studied group after 4 weeks of treatment up to the normal values and they maintained at that level until the end of the treatment and followup (12 weeks). The ALT activity in Bicyclol group significantly differed from that in the control group where there was no reported statistically significant decrease in the activity of the enzyme during the follow-up (Table 2).

ALT activity (U/I) in patients of the studied and control groups on the $4^{\text {th }}$ and $12^{\text {th }}$ weeks of treatment

\begin{tabular}{|c|c|c|c|c|c|}
\hline Index & Group & $\mathrm{N}$ & Mean (M) & SD & p-value* \\
\hline \multirow{2}{*}{$4^{\text {th }}$ week } & Studied & 34 & 39.53 & 20.07 & \multirow{2}{*}{$<0.001^{* *}$} \\
\cline { 2 - 6 } & Control & 17 & 130.84 & 98.44 & \\
\hline \multirow{2}{*}{$\begin{array}{c}12^{\text {th }} \\
\text { week }\end{array}$} & Studied & 34 & 48.34 & 33.58 & \multirow{2}{*}{$<0.001 * *$} \\
\cline { 2 - 5 } & Control & 17 & 102.58 & 56.12 & \\
\hline
\end{tabular}

* Data evaluation was made by comparing the means using the Mann-Whitney test.

$\star \star$ The differences between the groups are statistically significant.

Comparative evaluation of the clinical manifestations of $\mathrm{CHC}$ before and after 12 weeks of therapy showed no statistically significant behavior within each group of patients and no differences between the studied and control groups. At the same time, a mean value on the subscale «General fatigue» was significantly reduced in patients of Bicyclol (Table 3). In the control group, the same effect was not obtained. There were no differences between the groups.
Table 3

Comparison of the mean values of the test results using the scale MFI-20 in studied and control groups before and after the treatment with Bicyclol ${ }^{\circledR}$

\begin{tabular}{|c|c|c|c|c|}
\hline \multirow{2}{*}{ Index } & \multirow{2}{*}{ Group } & \multicolumn{2}{|c|}{$\begin{array}{l}\text { Mean values by the } \\
\text { scale MFI- } 20\end{array}$} & \multirow{2}{*}{$\mathrm{p}$-value } \\
\hline & & $\begin{array}{l}\text { Before } \\
\text { treatment }\end{array}$ & $\begin{array}{c}\text { After } \\
\text { treatment }\end{array}$ & \\
\hline \multirow{2}{*}{$\begin{array}{l}\text { General } \\
\text { fatigue }\end{array}$} & Studied & 11.82 & 10.26 & $0.006 * *$ \\
\hline & Control & 11.88 & 11.00 & 0.173 \\
\hline \multirow{2}{*}{$\begin{array}{l}\text { Physical } \\
\text { fatigue }\end{array}$} & Studied & 10.53 & 11.29 & 0.120 \\
\hline & Control & 10.71 & 10.29 & 0.463 \\
\hline \multirow{2}{*}{$\begin{array}{l}\text { Reduced } \\
\text { activity }\end{array}$} & Studied & 11.41 & 10.65 & 0.233 \\
\hline & Control & 10.82 & 9.94 & 0.079 \\
\hline \multirow{2}{*}{$\begin{array}{l}\text { Reduced } \\
\text { motivation }\end{array}$} & Studied & 8.38 & 8.18 & 0.734 \\
\hline & Control & 9.18 & 8.76 & 0.510 \\
\hline \multirow{2}{*}{$\begin{array}{l}\text { Mental } \\
\text { fatigue }\end{array}$} & Studied & 8.97 & 9.65 & 0.374 \\
\hline & Control & 8.06 & 9.53 & 0.134 \\
\hline \multirow{2}{*}{ Total } & Studied & 51.12 & 50.00 & 0.399 \\
\hline & Control & 50.76 & 48.94 & 0.326 \\
\hline
\end{tabular}

* Data evaluation was performed by the intragroup pair-wise comparison of the mean values obtained during the two visits, using the Wilcoxon test.

${ }_{\star \star}$ The differences are statistically significant.

There were no differences between patients in both groups in the value of other biochemical parameters at the end of treatment and follow-up. At the same time, on the $12^{\text {th }}$ week of treatment statistically significant decrease of AST activity and concentration of indirect and total bilirubin in patients of Bicyclol group was shown (Table 4).

It was shown that in patients receiving Bicyclol, there was increased GGT activity on the $12^{\text {th }}$ week of treatment (Table 4). In 5 patients of that group significant increase in GGT activity was reported, which was considered as an adverse event. Analysis of individual data of these patients showed that such increased GGT activity could not certainly be attributed to manifestations of Bicyclol intolerance, because each of these patients had related gastrointestinal disease (chronic cholecystitis, chronic pancreatitis etc.). Further analysis of the GGT activity behaviour in the group of patients received Bicyclol after exclusion of these 5 patients showed no statistically significant differences between groups.

Table 4

Comparison of the mean values of the AST activity and serum bilirubin concentrations in the studied and control groups before and after the treatment with Bicyclol ${ }^{\circledR}$

\begin{tabular}{|c|c|c|c|c|}
\hline \multirow[b]{2}{*}{ Index } & \multirow[b]{2}{*}{ Group } & \multicolumn{2}{|c|}{ Result } & \multirow[b]{2}{*}{ p-value* } \\
\hline & & $\begin{array}{c}\text { Before } \\
\text { treatment }\end{array}$ & $\begin{array}{c}\text { After } \\
\text { treatment }\end{array}$ & \\
\hline \multirow{2}{*}{ AST (U/I) } & Studied & 80.08 & 68.34 & $0.025^{* *}$ \\
\hline & Control & 80.47 & 87.62 & 0.492 \\
\hline \multirow{2}{*}{$\begin{array}{l}\text { Total } \\
\text { bilirubin } \\
(\mu \mathrm{mol} / \mathrm{I})\end{array}$} & Studied & 17.50 & 14.18 & $0.010^{* *}$ \\
\hline & Control & 19.33 & 17.26 & 0.084 \\
\hline \multirow{2}{*}{$\begin{array}{l}\text { Direct } \\
\text { bilirubin } \\
(\mu \mathrm{mol} / \mathrm{l})\end{array}$} & Studied & 4.75 & 3.81 & 0.091 \\
\hline & Control & 4.94 & 5.02 & 0.717 \\
\hline \multirow{2}{*}{$\begin{array}{l}\text { Indirect } \\
\text { bilirubin } \\
(\mu \mathrm{mol} / \mathrm{l})\end{array}$} & Studied & 12.75 & 10.06 & $0.028^{* *}$ \\
\hline & Control & 14.33 & 11.76 & 0.070 \\
\hline \multirow{2}{*}{ GGT (U/I) } & Studied & 74.47 & 89.39 & $0.018^{* *}$ \\
\hline & Control & 78.09 & 77.16 & 0.287 \\
\hline
\end{tabular}

* Data evaluation was performed by the intragroup pair-wise comparison of the mean values obtained during the two visits, using the Wilcoxon test.

$\star \star$ The differences are statistically significant. 
Course of the therapy with Bicyclol had no effect on viral load, there were also no differences between the groups.

Compliance assessment by the number of taken tablets, carried out on the $4^{\text {th }}$ and $12^{\text {th }}$ weeks of treatment showed that patients received Bicyclol and placebo for 12 weeks in full compliance with the protocol. The index of compliance was of more than $80 \%$.

There were no reports of any serious adverse events to Bicyclol. Adverse events were manifested primarily by the laboratory abnormalities (increased prothrombin time, increased alkaline phosphatase and GGT levels). In addition, there were 3 registered cases of adverse drug reactions, manifested by nausea, epigastric pain and elevated AST, which are specified in the package insert. In all cases, patients who have reported adverse drug reactions also had satisfactory compliance that led to the conclusion of a good Bicyclol tolerability.

The data of the positive effects of Bicyclol to biochemical activity of the pathological process in patients with $\mathrm{CHC}$ predetermine Bicyclol's study in the treatment of other liver pathologies. For

\section{References}

1. European Association for the Study of the Liver. EASL Clinical Practice Guidelines: management of hepatitis C virus infection J. Hepatol. 2014:60:392-420.

2. Ferenci P., Bernstein D., Lalezari J. et al. ABT-450/rombitasvir and dasabuvir with or without ribavirin for HCV. N. Engl. J. Med. 2014;370:1983-1992.

3. Han Y., Shi J.-P., Ma A.-L. et al. Randomized, vitamin E controlled trial of Bicyclol plus metformin in non-alcoholic fatty liver disease patients with impaired fasting glucose. Clin. Drug Investig. 2014;34(1):1-7.

4. Liu G. T. Bicyclol: a novel drug for treating chronic viral hepatitis B and C. Med. Chem. 2009;5(1):29-43.

5. Liu G. T., Li Y., Wei H. L. et al. Mechanism of protective action of bicyclol against $\mathrm{CCl}$-induced liver injury in mice. Liver Int. 2005;25(4):872-879.

6. Manns M. Marcellin P., Poordad F. et al. Simeprevir with pegylated interferon alfa $2 \mathrm{a}$ or $2 \mathrm{~b}$ plus ribavirin in treatment-naive patients with chronic hepatitis $\mathrm{C}$ virus genotype 1infection (QUEST-2): a randomised, double-blind, placebo-controlled phase 3 trial. Lancet. 2014;384:414426.

7. Pan S. Y. Dong H., Yu Z. L. et al. Bicyclol, a synthetic dibenzocyclooctadiene derivative, decreases hepatic lipids but increases serum triglyceride level in normal and hypercholesterolaemic mice. J. Pharm. Pharmacol. 2007;59(12):1657-1662. example, recently we obtained data on the Bicyclol effectiveness in the treatment of non-alcoholic fatty liver disease - Bicyclol reduced the signs of steatohepatitis histological activity, reduced transaminases levels [3]. It seems advisable to conduct further clinical trials of Bicyclol in patients with non-alcoholic steatohepatitis (NASH), as well as in patients with toxic liver injury - both alcohol or drug etiology.

Conclusions. Thus, the study showed that treatment of patients with $\mathrm{CHC}$ (moderate activity) with the original Bicyclol ${ }^{\circledR}$ medicine at a daily dose $150 \mathrm{mg}$ for 12 weeks is followed by a decrease in ALT and AST levels, and bilirubin concentrations, and reduces the severity of the manifestations of asthenic-vegetative syndrome. The tested drug is characterized by good safety profile and good tolerability. Bicyclol ${ }^{\circledR}$ can be recommended for the treatment of patients with $\mathrm{CHC}$ who failed to respond to antiviral therapy or who have contraindications for it, to reduce the activity of the inflammatory process and the rate of progression of the disease.

8. Smets E. M. Garssen B., Bonke B., De Haes J. C. The Multidimensional Fatigue Inventory (MFI) psychometric qualities of an instrument to assess fatigue. Psychosom. Res. 1995;39(3):315-325.

9. Su H. L., Zhu Y. X., Gao Z. J. et al. Ef cacy comparison between bicyclol and polyene phosphatidylcholine treatments for the patients with nonalcoholic fatty liver disease. Chin. J. Hepatol. 2011;19(7):552-553.

10. Sulkowski M. S. Gardiner D. F., Rodriguez-Torres M. et al. Daclatasvir plus sofosbuvir for previously treated or untreated chronic HCV infection N. Engl. J. Med. 2014;370:211-221.

11. Wang H., Li Y. Protective effect of bicyclol on acute hepatic failure induced by lipopolysaccharide and D-galactosamine in mice. Eur. J. Pharmacol. 2006;53(13):194-201.

12. Xie W. A., Shi G., Zhang $H$. et al. randomized, multi central, controlled study of patients with hepatitis B e antigen-positive chronic hepatitis B treated by adefovir dipivoxil or adefovir dipivoxil plus bicyclol. Hepatol. Int. 2012;6(2):441-448.

13. Zeuzem S., Andreone P., Pol S. et al. Telaprevir for retreatment of HCV infection N. Engl. J. Med. 2011;364:24172428.

14. Zhao J., Chen H., Li Y. Protective effect of bicyclol on acutealcohol-induced liver injury in mice. Eur. J. Pharmacol. 2008;586(1-3):322-331.

\section{About authors:}

Geyvandova Natalia Iogannovna, MD, PhD, Professor, Department of Hospital Therapy, Stavropol State Medical University, Russia; tel.: +79624452246; e-mail: ngeyvandova@yandex.ru

Lioznov Dmitriy Anatolevich, MD, PhD, Professor, Head of Department of Infectious Diseases and Epidemiology,

Pavlov First Saint Petersburg State Medical University, Russia;

tel.: +79219095103; e-mail: dlioznov@yandex.ru

Morozov Vyacheslav Gennadevich, MD, PhD, Professor, Head of Samara medical company «Hepatologist», Russia; tel.: +79608121109; e-mail: viacheslavmorozov@yandex.ru

Yagoda Alexander Valentinovich, MD, PhD, Professor, Head of Department of Hospital Therapy,

Stavropol State Medical University, Russia;

tel.: +79064907330; e-mail: alexander.yagoda@gmail.com

Liu Geng Tao, MD, PhD, Professor, Department of Pharmacology, Institute of Materia Medica,

Chinese Academy of Medical Sciences, China

Han Ying, MD, PhD, Professor, Department of Gastorenterology, Xijing Hospital of Digestive Diseases, The Fourth Military Medical University, China; tel.: +7(6029)84775507; e-mail: hanying@fmm.edu.cn 